\title{
MARKET SEGMENTATION IN AIR TRANSPORTATION IN SLOVAK REPUBLIC
}

\author{
Marek PILAT*, Stanislav SZABO, Sebastian MAKO, Miroslava FERENCOVA \\ Technical university of Kosice, Faculty of aeronautics \\ *Corresponding author. marek.pilat@tuke.sk
}

\begin{abstract}
This article talks about segmentation of air transport market in the Slovak Republic. The main goal was to explore all regular flights from three International airports in Slovak Republic. The researched airports include M.R. Štefánik in Bratislava, Košice International Airport and Poprad Tatry Airport. The reason for the selection of airports was focused on scheduled flights. The main output of the work is a graphical representation of scheduled flights operated from the territory of the Slovak Republic. The work includes an overview of airlines, destinations, attractions, and other useful information that has come up with this work.
\end{abstract}

Keywords: Airport; segmentation; scheduled flights

\section{INTRODUCTION}

The main aim of this article is to point out the coverage of the air transport market from the territory of the Slovak Republic. Initial information was processed for three International airports and their regular flights to different parts of the world. We chose M.R. Stefanik in Bratislava, Kosice International Airport and Poprad - Tatry Airport. In practical part the authors collected all regular flights from the airports and processed them in table form. All these lines were needed to develop a comprehensive graphical model which is also the main output. The graphical model clearly shows where it can be reached from the territory of the Slovak Republic by a direct route. All data is current for the 2018/2019 Winter Timetable with all the current changes, whether in terms of line cancellation or adding new carriers to new destinations.

Service quality delivery in a cross-national context where authors said that Consumption of a broad range of services ranging from tourism to hospitality by an increasingly global mix of customers, especially from the new millennium of the emerging middle class, is creating an interesting challenge for service providers [1]. Explaining changes and trends in the airline industry: Economies of density, multiproduct scale, and spatial scope where authors said that changes in the shape and size of airline networks have not been explained clearly from a cost perspective based on the finding of increasing returns to density for given route structures and constant returns to scale for variable network size [2]. The economic effects of air transportation where author dealt with the economic strength of world regions it is important to analyse the changing regulatory framework that actuated fundamental impacts on airline competition and air transportation. The various stages of openness in global aviation markets have implications on special patterns of air industry and market power in several continents [3]. Air transport liberalization and its effects on airline competition and traffic growth - an overview where author said that liberalization allows airlines to optimize their networks, and thus may introduce substantial demand and financial uncertainty to airports. Vertical arrangements between airlines and airports may offer a wide range of benefits to the parties involved, yet such arrangements could also lead to airline entry barriers which reduce the effects of liberalization [4]. Flight delays, capacity investment and social welfare under air transport supply-demand equilibrium where authors analyse benefits from aviation infrastructure investment under competitive supply-demand equilibrium. The analysis recognizes that, in the air transportation system where economies of density is an inherent characteristic, capacity change would trigger a complicated set of adjustment of and interplay among 
passenger demand, air fare, flight frequency, aircraft size, and flight delays, leading to an equilibrium shift [5].

\section{SCHEDULED FLIGHTS FROM CHOOSEN SLOVAK INTERNATIONAL AIRPORTS}

To elaborate this article we chose the three largest airports in Slovakia and their connection with the rest of the world. The essence is the elaboration and graphic representation of all scheduled flights operating from the territory of the Slovak Republic from the three largest airports Bratislava, Kosice and Poprad.

\subsection{Flights from M.R. Stefanik in Bratislava}

Bratislava Airport provides the largest number of scheduled routes from chosen airports. Airlines represented at Bratislava Airport operating scheduled connections for the current winter flight schedule 2018/2019 are Ryanair, CSA, Pobeda, WizzAir, Air Cairo, Fly Dubai, Ukraine International Airlines and Georgian Airways. The largest number of flights have Irish low-cost carrier Ryanair over the Hungarian low-cost carrier Wizz Air.

Table 1 Scheduled flights winter schedule 2018/2019 from BTS

\begin{tabular}{|c|c|}
\hline Airline & Destination (IATA code) \\
\hline Ryanair & Athens (ATH) \\
\hline Ryanair & Barcelona - Gerona (GRO) \\
\hline Ryanair & Birmingham (BHX) \\
\hline Ryanair & Bologna (BLQ) \\
\hline Ryanair & Brusel - Charleroi (CRL) \\
\hline Fly Dubai & Dubaj (DXB) \\
\hline Ryanair & Dublin (DUB) \\
\hline Ryanair & Edinburgh (EDI) \\
\hline Ryanair & Eilat-Ovda Israel (VDA) \\
\hline Ryanair & Eindhoven (EIN) \\
\hline Air Cairo & Hurghada (HRG) \\
\hline $\begin{array}{l}\text { Czech Airlines } \\
\text { (SmartWings) }\end{array}$ & Kosice (KSC) \\
\hline Ryanair & Kyjev - Borispol (KBP) \\
\hline Wizz Air & Kyjev - Žuljany (IEV) \\
\hline Ryanair & Leeds - Bradford (LBA) \\
\hline Wizz Air & London - Luton (LTN) \\
\hline Ryanair & London - Stansted (STN) \\
\hline Wizz Air & L'vov $(\mathrm{LWO})$ \\
\hline Ryanair & Madrid (MAD) \\
\hline Ryanair & Manchester (MAN) \\
\hline Ryanair & Marakesh (RAK) \\
\hline Air Cairo & Marsa Alam (RMF) \\
\hline Ryanair & Milan - Bergamo (BGY) \\
\hline Pobeda & Moskow - Vnukovo (VKO) \\
\hline Ryanair & Niš (INI) \\
\hline Ryanair & Pafos - Cyprus (PFO) \\
\hline Ryanair & Paris - Beauvais (BVA) \\
\hline $\begin{array}{l}\text { Czech Airlines } \\
\text { (SmartWings) }\end{array}$ & Prague $(\mathrm{PRG})$ \\
\hline Ryanair & Rome - Ciampino (CIA) \\
\hline
\end{tabular}




\begin{tabular}{|c|c|}
\hline Wizz Air & Skopje (SKP) \\
\hline Wizz Air & Sofia (SOF) \\
\hline Georgian Airways & Tbilisi (TBS) \\
\hline Ryanair & Thessaloniki (SKG) \\
\hline
\end{tabular}

Table 1 shows all flights from M.R. Stefanik in Bratislava for winter flight schedule 2018/2019.

Specifies the name of the airline and the destination with the IATA code. It's clear from the table that Ryanair and Wizz Air have the largest share on the market. These two low-cost companies provides many interesting destinations from Bratislava Airport where customers can travel. With this type of transportation the standard is lower transport comfort, attractive prices and regularity.

\subsection{Flights from Kosice International Airport}

Kosice International Airport as the second largest airport in Slovakia it has the advantage of the number of traditional airlines. Austrian Airlines, Turkish Airlines, Lot Polish Airlines and Czech Airlines are among the traditional airlines that provide scheduled air transportation to the world's largest hub airports. Czech Airlines is currently operating under the brand name Smart Wings and there are many changes in the company's overall management. Since January 2019, the only one national route from Kosice to Bratislava has been cancelled due to the unification of the fleet and the decommissioning of the ATR 42 and 72 aircrafts. Low cost airlines represented by Wizz Air, Eurowings and Ryanair since April 2019. In the case of Eurowings, it is difficult to classify it as a low-cost or traditional carrier. It's a hybrid airline with classic and low cost services. For example connection flights, transport not only in economy class, premium services, etc. This company can be defined as a hybrid as it links the services of low-cost and classic carriers and figures in Lufthansa Group.

Table 2 Scheduled flights winter schedule 2018/2019 from KSC

\begin{tabular}{|c|c|}
\hline Airline & Destination (IATA code) \\
\hline Czech Airlines (SmartWings) & Prague (PRG) \\
\hline LOT Polish Airlines & Warsaw (WAW) \\
\hline Czech Airlines (SmartWings) & $\begin{array}{c}\text { Prague via Bratislava } \\
\text { (PRG via BTS) }\end{array}$ \\
\hline Wizz Air & London - Luton (LTN) \\
\hline Eurowings & Dusseldorf (DUS), Munich (MUC) \\
\hline Austrian Airlines & Vienna (VIE) \\
\hline Turkish Airlines & Istanbul (IST) \\
\hline
\end{tabular}

Tab. 2 shows all scheduled flights from Kosice Airport for the winter schedule. The table doesn't include the line with the departure number OK025 KSC-OSR-PRG which is rarely included in the flight schedule. Table 2 doesn't include the new Ryanair flight from April 2, 2019 on the KSC-SEN (London - Southend Airport) route.

\subsection{Flights from Poprad - Tatry Airport}

Poprad Airport was included into this article as the third International airport with scheduled flights operated from the territory of the Slovak Republic. According to the available winter schedule airport have flights to London - Luton, Riga and the latest route to Kiev. The airlines represented at the airport that fly the above-mentioned lines are Wizz air, Air Baltic and SkyUp. 
Table 3 Scheduled flights winter schedule 2018/2019 from TAT

\begin{tabular}{|c|c|}
\hline Airlines & Destination (IATA code) \\
\hline Wizz air & London - Luton (LTN) \\
\hline Air Baltic & Riga (RIX) \\
\hline Sky Up & Kyjev - Zhulhany (IEV) \\
\hline
\end{tabular}

As can be seen from Table 3 the airport have three scheduled flights. In the resulting graphical representation the TAT-IEV line is currently omitted due to late inclusion into the winter schedule 2018/2019. This line has been flown since 29DEC18 by Ukrainian low cost SkyUP and the graphic model was drafted before the date of inclusion of this route.

\subsection{Scheduled flights graphical model}

The main output of this work is shown in Figure 1. The main aim of this work is a graphical representation of scheduled flights from three International airports in Slovakia. Several conclusions can be deduced from the previous subchapters. One of them is the fact that the largest market share of air transportation from the territory of the Slovak Republic has a low-cost airline Ryanair. The market share was dominated by low-cost companies and many other factors that will be discussed at the end of this article.

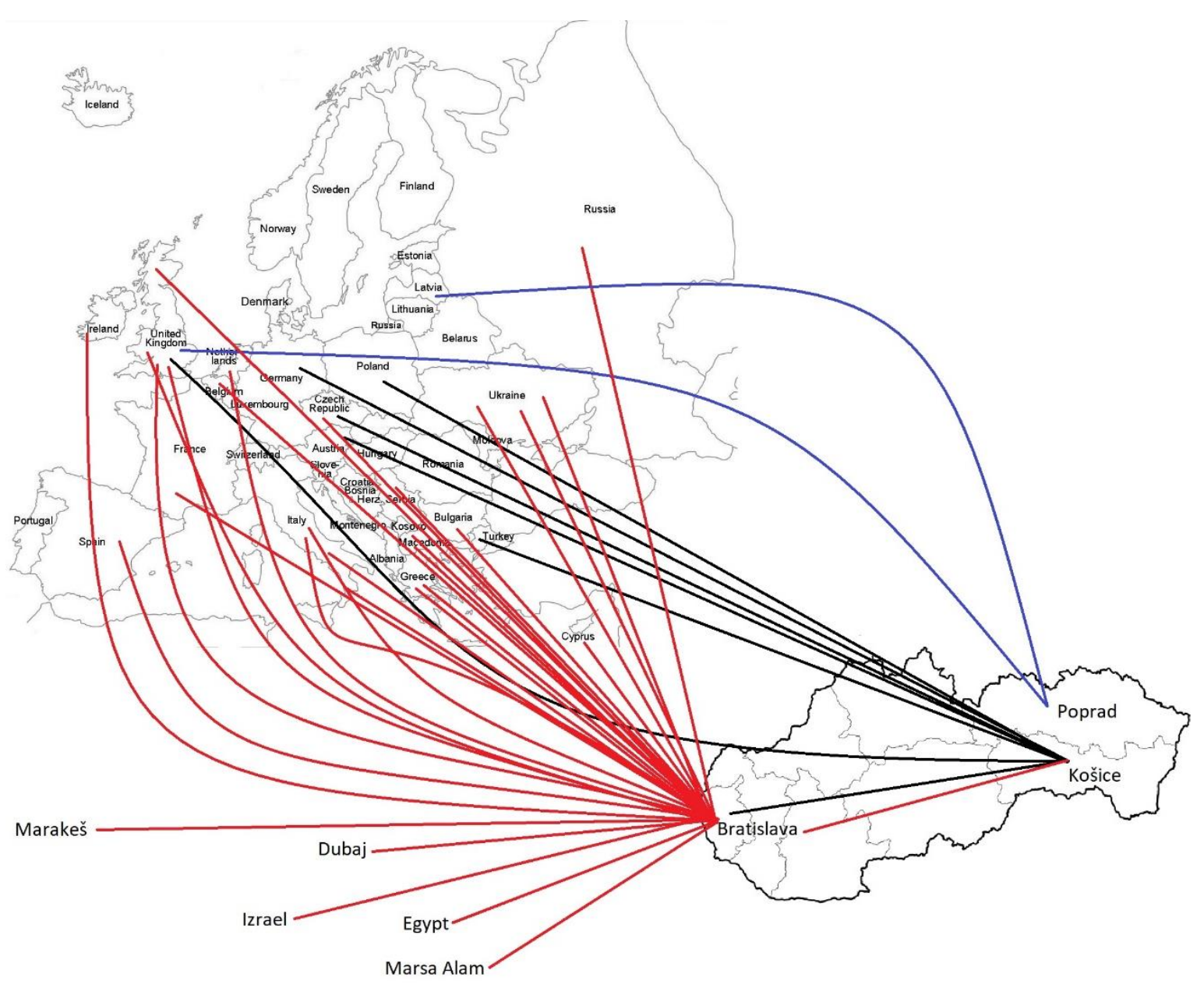

Figure 1 Scheduled flights and its graphical model on routes from Slovak Republic 


\section{CONCLUSION}

The main output is a graphical representation of all scheduled flights from the territory of the Slovak Republic. M.R. Stefanik in Bratislava gives to customers many interesting destinations around the world. Low-cost airlines Ryanair and Wizz air have a distinctive superiority. Most of the flights from Bratislava are to the UK (London) and Ireland (Dublin) as the airport management said at the last press conference. The airport in Kosice has its business plan developed in a different direction than the Bratislava airport. In Kosice traditional carriers are predominantly ahead of those low-cost carriers. The basic fact is that, on the routes of classic carriers there is a higher transport comfort, connection flights and many other benefits. The low-cost carrier Wizz air on route to London-Luton has deployed the Airbus A321 with capacity up to 230 passengers. News at the Kosice airport include the arrival of Eurowings (Munich, Dusseldorf), the cancellation of the Košice - Bratislava line, the arrival of Ryanair in April 2019 and the opening of the Košice - London Southend route and others. Poprad Tatry Airport offers currently 3 scheduled flights to London, Riga and Kiev. Due to the late addition of the Poprad - Kiev line this line is not drawn in the resulting chart. It's the latest flight flying by Ukrainian low-cost SkyUp has been added to the flight schedule at the end of December 2018.

From the graphic representation you can easily read the prevalence of Bratislava Airport lines and also the diversity of individual destinations. When segmenting the air transport market in the Slovak Republic it was found that Ryanair has an undeniable superiority and that the market was dominated by low-cost companies in overall. It should be noted that although Kosice Airport offers fewer routes, passengers can travel to a number of destinations. Companies such as Turkish Airlines, Lot Polish Airlines, Austrian Airlines and Czech Airlines (Smartwings) offer passengers connections and allowing them to travel to more than 500 destinations around the world.

This topic was chosen mainly to show the current coverage of scheduled flights from the Slovak Republic to the outside world.

\section{References}

[1] Zhu, Y. \& et al. Service quality delivery in a cross-national context. In: International Business Review Volume 27, Issue 5, October 2018, Pages 1022-1032

[2] Jara-Diaz, S.R., \& et al., Explaining changes and trends in the airline industry: Economies of density, multiproduct scale, and spatial scope. In: Transportation research part e-logistics and transportation review Volume: 60 Pages: 13-26 Special Issue: SI DOI: 10.1016/j.tre.2013.09.003 DEC 2013

[3] Bogai, D., Wesling, M., The economic effects of air transportation. In: Airports and the Automotive Industry: Security Issues, Economic Efficiency and Environmental Impact January 2013, Pages 97-124

[4] Fu, XW. Oum, TH., Air transport liberalization and its effects on airline competition and traffic growth - an overview. In: Economics of international airline transport Book Series: Advances in Airline Economics Volume: 4 Pages: 11-44 DOI: 10.1108/S2212-160920140000004000 2014

[5] Zou, B., Hansen, M., Flight delays, capacity investment and social welfare under air transport supply-demand equilibrium. In: Transportation research part-a policy and practice Volume: 46 Issue: 6 Pages: 965-980 Special Issue: SI DOI: 10.1016/j.tra.2012.02.015 JUL 2012

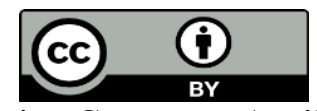

Article is licensed under a Creative Commons Attribution 4.0 International License 